\title{
CSR and Covid-19: Redefining the practices of CSR in context of Indian Industries
}

\author{
Ashish Saxena $^{1} \bullet$ Ved Prakash Bansal ${ }^{2}$ \\ ${ }^{1}$ Sharda University, Greater Noida \\ ${ }^{2}$ Satyawati College (Eve.), University of Delhi \\ Email Id: $\underline{\text { asaxena396@gmail.com }}$ •
}

\begin{abstract}
This article is an endeavor to identify the impact of corona virus on CSR practices followed by the Indian companies and how this pandemic opens a new and innovative way of improving the CSR practices followed by the different companies. Every coin has two aspects and therefore we are in strong proposition that Covid-19 crisis along with its adverse and serious damages, also creates a opportunity for the business units to shift their traditional CSR practices towards the more genuine and authentic ways for serving the humanity in a more better and improved way. In our discussion, we outline, that how the earnings of business units are affected and how they are improving their ways of addressing the CSR practices and helping the government in the war against this virus. We end the paper with a identifying a number of potentially fruitful contributions made by the different units and celebrities of our country for fighting against this deadly virus.
\end{abstract}

Keywords: Covid-19, CSR, Innovative, Crisis

\section{Introduction}

The voluntary fulfillment and compliance of ecological and social responsibility of companies is known as its Corporate Social Responsibility (CSR) and it is widely used term in era of current business environment. According to the Section 135 Schedule VII of Companies Act 2013, companies with networth of Rs.500 Cr. or above profit of Rs. 5 Cr. Or above a turnover of Rs. 1000 crore or above in the previous financial year must have a corporate social responsibility (CSR) committee. The company is required to utilize atleast 2 per cent of the average net income earned during the preceding financial years towards fulfilling the activities involving customers, suppliers, employees, business partners, investors and shareholders dealing with corporate social responsibility. 
But the current picture of the world has completely changed the global scenario and now a days, business are facing a lot of problems since the corona virus epidemic came to know on December 31, 2019 when China clued-up the World Health Organization of a bunch of cases of pneumonia in Wuhan City in Hube Province. Afterwards the disease spread to more states in China, and to the rest of the world and therefore WHO has to declare it as a pandemic. Entire world is facing this pandemic with a great degree of uncertainty. On one hand people are losing their lives and on the other hand people which are not affected or infected by this deadly virus, are losing their jobs and means of livelihood. Indian economy is also not different and currently there are two major challenges before the Indian government, firstly to control the spread of this virus which is something like a health emergency and secondly to save and protect the economy from the severe crisis of recession and depression. Lockdown at the national and international level creates the problem of livelihoods for the people of a country. Country like USA is now on their knees, certainly because of this pandemic and therefore it badly hits the world economy as directly or indirectly every country is somewhat related and connected to the world's Superpower America.

Economies across the globe are facing serious troubles and International Monetary Fund (IMF) already predicted that many nations of the world, including India, may face a negative growth trajectory during the year 2020 on account of this Corona virus pandemic. Like IMF, World trade Organization (WTO) also predicted that the world trade is set to crash down by between 13 and $32 \%$ in 2020 due to the COVID-19 pandemic, perhaps the maximum decline since the great depression of 1930s. But as a ray of hope, World Economic Outlook, the IMF projects a bounceback for the Indian economy in the year 2021 with a nice rate of $7.4 \%$.

Covid-19 pandemic has made a huge loss to almost every sector of the economy whether it is MSMEs, foreign trade etc. it disturbed the normal economic activity and bring people at the door of losing their jobs. In this tough moment, companies are at the stage of economic crisis and people are facing a serious drop in their levels of income which indirectly affects their demand and ultimately less demand by the people of a nation leads to less production by the companies. So all in all, this chain is interlinked in such a way that they act and react on one another. And therefore to save the Indian economy, RB decreases the base rate and other MCLR based loan rates just to infuse some liquidity into the dead markets. 
Many nations of the world declared relief packages to minimize the effect of this economic crisis like USA has announced a package of US\$ 2 trillion dollar which benefits the lower income groups of the society and partially it boosts up the MSMEs. In the same way, European Union has also planned to declare some economic packages for saving their economies. India is no different, and Prime minister of India declared a fourth largest relief package of the world approximately of $10 \%$ of India's GDP and stands at 20 lakh crores of Rs, but in a country like India, income transfer schemes are not the only solutions to the problem, apart from this it requires expansion of monetary policies so that a high degree of liquidity can be ensured and a lower interest rates can also increase the supply of money into the market leading to an increase in the level of production. According to a study, made by the Indian Society of Labour Economics (ISLE) job loss is the most brutal and immediate impact of covid-19 crisis and which leads to deepen the gap of inequality and lower economic growth.

The world has completely undergone a change with new dynamics under the novel coronavirus (COVID-19) pandemic. It has changed the perspective with which we view the world and the ways of living in it. The pandemic has brought in a lot of pain and scarred the communities causing psychological and emotional trauma. COVID-19 can be compared to Taleb (2008) known as 'Black swan event'- sudden occurrence of the events that drastically changes the world environment. Recent studies of authors like Grech 2020 and Mazzolen et al. noted the similar behavior in their study.

The influence of novel coronavirus (Covid-19) on the global economy is likely to be unparalleled since the time of Great Depression in 1930s (Euronews, 2020). The COVID-19 pandemic presents one of the most drastic and has made a significant environmental change in the modern business world, which could potentially have a strong impact on corporate social responsibility (CSR). The present paper focuses on CSR trends and opportunities to combat Covid-19.

\section{Problem Statement}

"Corporate social responsibility", is a widely and relentlessly adopted concept since its inception, and it has attracted a global and mass attention in increasingly incorporated world economy. Even though it is not a present-day concept, corporate social responsibility (CSR) has been developed into a global norm and many global and international companies are following this noble concept for the upliftment of deprived sections of the society. 
But, unfortunately the COVID 19 gives a very serious setback to both human being as well as industries. In order to protect people from the threat of corona virus Indian Government announced a severe lock down for more than 2 months, which in turns hits all type of units whether big, small or medium enterprises.

But many companies shows a great level of determination towards serving the humanity and fulfilled their responsibilities by making different kinds of donations to the PM Cares fund and other state government authorities to fight against covid-19. Companies also made payments to their temporary and daily wage workers during the period of lockdown shows their moral and humanitarian character and thus in this way they fulfilled their CSR activities towards the society.

We found that many companies not only have resisted the unfair trade practices but also they were proactively engaged in many CSR activities like in India, many manufacturing units transformed their units to produce ventilators, sanitizers, personal protective equipments, masks and so on. While many NGOs and other social units have distributed all these items of protection as free of cost to the needy sections of the society.

\section{Objectives of the Study}

i. To recognize and understand the practices of corporate social responsibility of Indian industries.

ii. To identify the corporate social responsibility practices adopted by industries during Covid-19 epidemic.

\section{Industries Contributed to PM Cares Fund}

In a direction to combat Covid-19, Government of India is stimulating and encouraging the companies to come forward for the social cause during this tough time of covid-19. On March 23, 2020, It was announce by the Ministry of Corporate Affairs that all the expenditures related to covid19 like support of health equipments, beds, masks, sanitizers, food will be added as the permissible transactions for CSR expenditure. After this announcement, many big giants of Indian economy contributed a lot to the PM CARES fund as shown table below:

\begin{tabular}{|l|l|}
\hline Contributor & Contribution \\
\hline Gautam Adani & Rs.100 Cr. \\
\hline
\end{tabular}




\begin{tabular}{|l|l|}
\hline Tata Sons and Tata Trusts & Rs.1500 Cr. \\
\hline Reliance Industries & Rs. $500 \mathrm{Cr}$. \\
\hline JSW Group & Rs.100 Cr. \\
\hline Sajjan Jindal & Equipment to healthcare workers and one day salary \\
\hline Kotak Mahindra Bank & $\begin{array}{l}\text { Rs.25 Cr. And Rs. 10 Cr. Towards Maharashtra CM } \\
\text { relief fund }\end{array}$ \\
\hline ITC limited & Rs.150 Cr. \\
\hline Vedanata & Rs.100 Cr. \\
\hline Mahindra \& Mahindra & Ventilators and health equipments \\
\hline Hero cycles & Rs.100 Cr \\
\hline Parle Products & 30 million packets of Parle G Food products \\
\hline Sun Pharma & Rs.25 Lakhs \\
\hline Curefit & Rs.4 Cr. \\
\hline
\end{tabular}

\section{New and innovative CSR practices adopted by different units during COVID-19}

There are certain other practices of corporate social responsibility which are selected by industries based on their expediency. In the given table, an analysis shows the CSR practices adopted by industries against the deadly virus in the study duration. The most common and general CSR practices are having ISO certification, maintained Quality, sponsorship and donation Education, provide health care facility, using eco friendly technology, planting tree, and so on. But during this crisis, the CSR practices are framed keeping in mind the needs of the suffered.

\begin{tabular}{|c|c|c|}
\hline S.No. & $\begin{array}{l}\text { Company } \\
\text { Name }\end{array}$ & Contribution to combat COVID-19 \\
\hline 1 & $\begin{array}{l}\text { Infosys } \\
\text { Foundation }\end{array}$ & $\begin{array}{l}\text { The company has contributed Rs } 50 \text { crore to PM CARES Fund and } \\
\text { an additional Rs. } 500 \mathrm{Cr} \text {. Utilized for testing purposes, ventilators, } \\
\text { health equipments, food and arrangement of } 100 \text { beds in Narayana } \\
\text { hospital. }\end{array}$ \\
\hline 2 & ITC Ltd & $\begin{array}{l}\text { Covid emergency fund worth Rs. } 150 \mathrm{Cr} \text {. To provide financial } \\
\text { assistance to the rural healthcare centers. }\end{array}$ \\
\hline 3 & $\begin{array}{l}\text { State Bank of } \\
\text { India }\end{array}$ & $\begin{array}{l}\text { The employees of SB together contributed a sum of Rs. } 100 \mathrm{cr} \text {. To } \\
\text { the PM cares fund. }\end{array}$ \\
\hline 4 & $\begin{array}{l}\text { Hindustan } \\
\text { Unilever Ltd }\end{array}$ & $\begin{array}{l}\text { The company has contributed Rs. } 100 \text { cr.and price cut and discounts } \\
\text { on hand sanitizers, floor cleaners and disinfectants for hospitals and } \\
\text { the underprivileged persons. }\end{array}$ \\
\hline
\end{tabular}




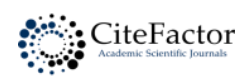

\begin{tabular}{|l|l|l|}
\hline 5 & TCS & $\begin{array}{l}\text { The company has helped covid affected patients by supplying } \\
\text { ventilators, patient trackers, health kits, TCS iON digital classroom } \\
\text { systems for online teaching and learning process. }\end{array}$ \\
\hline 6 & $\begin{array}{l}\text { Reliance } \\
\text { Industries Ltd }\end{array}$ & $\begin{array}{l}\text { The company has contributed 100 bed to the designated COVID19 } \\
\text { hospitals, free meals, masks, PPE kit for healthcare workers. }\end{array}$ \\
\hline
\end{tabular}

Source: Secondary data

Undoubtedly, CSR actions are proposed for the support of society starting with the contribution from the employees of the companies. Many companies have resorted to work from home and use of masks and sanitizers and strict adherence to hygiene like regular washing of hands, use of disinfectants in the premises etc.

\section{Conclusions}

Corporate social responsibility (CSR) has evolved itself into a universal norm and innovative patterns of global power have emerged to smooth the progress of the ability to reach combined decisions on intercontinental issues. This study has given a brief note on how industry is taking essential steps with government in this epidemic so that life and livelihood of the people can be ensured. It is high time that the corporate houses realize the responsibilities that they have to fulfil towards the society to create economic opportunities, and access to core services such as education, health and poverty mitigation. The CSR activities undertaken by the corporate houses during the COVID 19 pandemic definitely creates superior image, repute and name in the midst of their customers and it definitely pulls new business and new customers in the future.

\section{References:}

Aguinis, H., Villamor, I., \& Gabriel, K. P. (2020). Understanding employee responses to COVID-19: a behavioral corporate social responsibility perspective. Management Research. https://doi.org/10.1108/MRJIAM-06-2020-1053

Corporate Social Responsibility and Competitiveness ( Essential of the Corporate India and its Sustainability) Patron: Rusen Kumar, Editor: Saurabh Mittal, Publisher: Allied Publisher Private Ltd., New Delhi.

Euronews (2020), 'COVID-19: World economy in 2020 to suffer worst year since 1930s Great Depression, says IMF’, accessible at: https://www.euronews.com/2020/04/14/

Grech, Victor (2020). "Unknown unknowns - COVID-19 and potential global mortality”, Early Human Development, 144, May 2020, doi.org/10.1016/j.earlhumdev.2020. 
Hamid, A. R. A. H. (2020). Social responsibility of medical journal: A concern for covid-19 pandemic. Medical Journal of Indonesia. https://doi.org/10.13181/mji.ed.204629

Harris. 1 and Hongwe (2020) "The impact of Covid-19 pandemic on corporate social responsibility and marketing philosophy” Journal of Business Research 116 (2020) pp no. 176-182

Kytle, B., \& Ruggie, J. G. (2005). Corporate Social Responsibility as Risk Management: A Model for Multinationals. Corporate Social Responsibility Initiative.

Mazzoleni, Stefano, Turchetti, Giuseppe, \& Ambrosino, Nicolino (2020). The COVID-19 outbreak: From "black swan" to global challenges and opportunities. Pulmonology, 26(3), 117-118. https://doi.org/10.1016/j.pulmoe.2020.03.002.

Ozili, P. K., \& Arun, T. (2020). Spillover of COVID-19: Impact on the Global Economy. SSRN Electronic Journal. https://doi.org/10.2139/ssrn.3562570

Wendy Chapple and Jeremy Moon, Corporate Social Responsibility (CSR) in Asia: A SevenCountry Study of CSR Web Site Reporting, Volume: 44 issue-4 